\title{
Contrasting pollination modes in three species of Licuala (Arecaceae: Coryphoideae)
}

\author{
A. S. Barfod, T. Burholt and F. Borchsenius
}

\begin{abstract}
Barfod, A.S., Burholt, T. and Borchsenius, F. (Dept. of Systematic Botany, Institute of Biological Sciences, University of Aarhus, Nordlandsvej 68, DK-8240 Risskov, Denmark) 2003. Contrasting pollination modes in three species of Licuala (Arecaceae: Coryphoideae). Telopea 10(1): 207-223. The pollination modes of Licuala spinosa, L. distans and L. peltata were studied in Peninsular Thailand. The differences in flowering behaviour and mechanisms that promote pollination are described. The pollen counts and frequent visits of calliphorid flies and halictid bees suggest that these are the most likely pollinators in L. spinosa followed by eumenid wasps and tachinid flies. Species of Trigona bees collected in the flowers of $L$. distans and L. peltata had high pollen loads. They were present during both anthesis and the receptive phase of the flowers and are probably responsible for pollination.
\end{abstract}

\section{Introduction}

About $14 \%$ of all palm species bear perfect flowers (Uhl 1969). This is lower than the corresponding 65\% for rain forest trees in general (Bawa 1979). Most of the perfect flowered palms are found in the tribe Corypheae, which comprises 31 genera. In this tribe only the two monotypic genera Guihaia and Kerriodoxa have unisexual flowers. Licuala belongs to the subtribe Livistoninae that includes twelve genera, all with hermaphroditic flowers. The gynoecium is composed of three carpels that are free at the base but joined in the stylar region. The genus consists of more than 150 species distributed in SE Asia from India in the west to Vanuatu in the east. It is the most species-rich genus of fan palms. Based on floral morphology, Furtado (1940) divided the genus into three subgenera: subgenus Libericula Furt. with discernible staminal filaments, subgenus Licuala with filaments fused into an androecial tube and all anthers inserted at the same level, and subgenus Pericycla (Bl.) Drude with anthers in two levels and an androecial tube.

Species of Licuala are typically palmlets or rosette palms growing in rainforest under low light conditions. One exception is L. spinosa Wurmb, which thrives in light, open and often disturbed habitats. Other species are found exclusively in habitat types such as freshwater swamp forests and limestone outcrops. The typical Licuala has armed petioles of differing lengths that position the fan-shaped blades at various levels and angles. The inflorescence varies from erect and overtopping the crown to short and hidden between the leaves. The inflorescence rachis has one to several nodes. At each node, a long tubular bract subtends a partial inflorescence that is either ramified or unbranched. The flowers are generally hermaphroditic and dichogamous but dioecy has been reported in a few instances (Uhl \& Dransfield 1987, Saw 1997, Barfod pers. obs.). Pollen morphology is very uniform throughout the genus (Ferguson 1987, Ferguson \& Harley 1993, Ambwani \& Kumar 1993).

Studies of the reproductive biology of palms have revealed a wide range of plant adaptations that match the behavioural characteristics of their pollinators (Henderson 1986, Zona 1987, Andersson et al. 1988, Herrera 1989, Olesen \& Balslev 1990, Barfod 
1991, Búrquez et al. 1987, Scariot et al. 1991, Listabarth 1992, Borchsenius 1993, Ervik 1993, Bernal \& Ervik 1996, Bøgh 1996, Listabarth 1996, Ervik \& Feil 1997, Küchmeister et al. 1997, Anstett 1999, Howard et al. 2001). The most common pollen dispersing agents are beetles followed by bees and flies. Except for Knuth (1904) who reported abundant nectar production in the flowers of Licuala grandis $\mathrm{H}$. Wendl., and listed some insects as likely pollinators, nothing has been published about pollination within this large genus.

\section{Materials and methods}

\section{Study organisms}

Licuala spinosa Wurmb (subgenus Licuala) is an understorey palm often with a large production of suckers. It is found in a range of habitats from ditches to forest understorey. It forms a dense crown and the petioles are armed with long spines. Inflorescences are typically erect and visible above the crown. The partial inflorescences are branched with up to seven rachillae (Fig. 1a).

Licuala distans Ridl. (subgenus Libericula) is a solitary palm restricted to the peninsular part of Thailand from Ranong in the north to Krabi in the south. It occurs in hill dipterocarp forest where it is locally very common, especially on ridges. The appearance of the crown is less dense than L. spinosa and the petioles are longer and more slender, and only armed basally. The lamina is finely divided into up to 35 segments, each folded two to three times. The inflorescences are gracefully bending and visible under the crown. The partial inflorescences are branched with up to five pendent rachillae (Fig. 1b).

Licuala peltata Roxb. ex Buch.-Ham. (subgenus Libericula) is also a solitary palm, widely distributed from India in the west to Peninsular Thailand in the east, barely extending across the border with Malaysia. It occurs in lowland dipterocarp forest where it is typically associated with limestone formations or local outcrops of calcareous rock. The crown carries only 5-10 leaves and the petioles are armed along their entire length. The number of segments per lamina varies from one in var. sumawongii L.G. Saw to 21, this figure being relatively constant throughout a population. The segments in divided leaves are 50-90 cm long, narrowly wedge-shaped to triangular. The inflorescences are erect and visible among the leaves. The partial inflorescences are spicate and pendent (Fig. 1c).

Morphological and anatomical features of importance for interaction with pollinating insects are summarised in Table 1.

\section{Study sites}

Licuala spinosa was studied at two sites in Peninsular Thailand (Fig. 2), the Khao Nor Chuchi Lowland Forest Project (KNC), located within the Khao Phra Bang Kham Wildlife Reserve in the Province of Krabi (99 $15^{\prime}$ E $07^{\circ} 55^{\prime}$ N, 20-80 m elevation) and the Thung Kai Arboretum (TKA) in the Province of Trang (99 38' E 07 27' N; 0-10 m elevation). At both sites L. spinosa was abundant. The study site at Khao Nor Chuchi is situated in a landscape of limestone hills covered with evergreen forest vegetation. Lime is precipitated in the soil in many places forming a water impermeable layer that causes flooding in the rainy season. Thung Kai Arboretum is situated near the sea. Here L. spinosa occur in open parkland vegetation dominated by Melaleuca cajuputi Powell, sedges and grasses. Patches of thicket are common composed of low trees and 

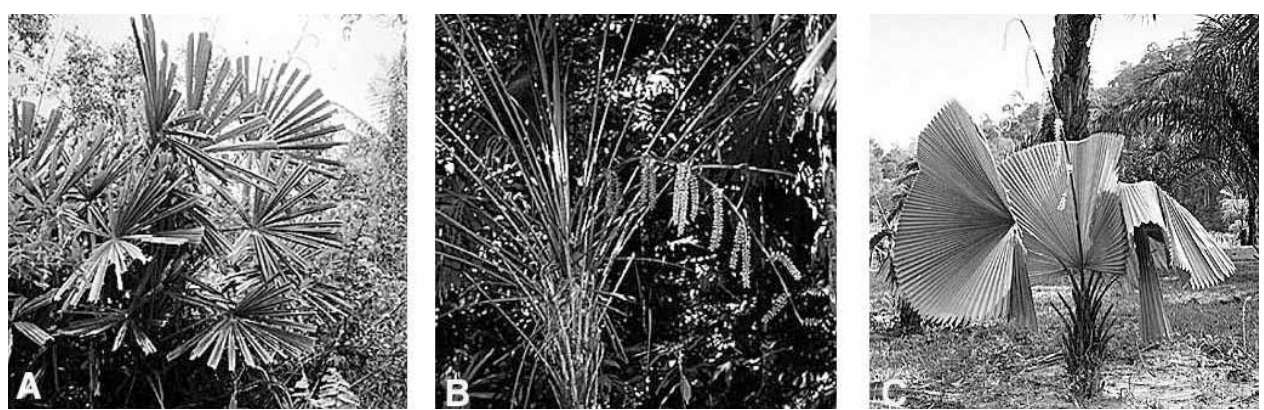

Fig. 1. Licuala habit. a, L. spinosa. b, L. distans. c, L. peltata.

Table 1. Comparison of Licuala spinosa, L. peltata and L. distans.

\begin{tabular}{|c|c|c|c|}
\hline Diagnostic feature & Licuala spinosa & Licuala distans & Licuala peltata \\
\hline growth form & clustering & solitary & solitary \\
\hline $\begin{array}{l}\text { average no. of rachillae per } \\
\text { partial inflorescence }\end{array}$ & $3.4(n=13)$ & $2.8(n=5)$ & $1.0(n=5)$ \\
\hline average length of rachillae $(\mathrm{cm})$ & $14.7(n=122)$ & $21.4(n=31)$ & $31.2(n=5)$ \\
\hline $\begin{array}{l}\text { average density of flowers } \\
\text { (number per } \mathrm{cm} \text { rachillae) }\end{array}$ & $9.61(n=311)$ & $4.05(n=5)$ & $5.98(n=5)$ \\
\hline average length of flower (mm) & $4.0(n=10)$ & $9.5(n=10)$ & $13.0(n=10)$ \\
\hline haircovering, calyx & dense & scattered & dense \\
\hline haircovering, corolla & hairy & glabrous & hairy \\
\hline sclereids, corolla & absent & present & absent \\
\hline filaments & fused into tube & fused basally & fused basally \\
\hline raphide ideoblasts in staminal tube & present & present & absent \\
\hline anther length (range in $\mathrm{mm}$ ) & $0.6-0.8$ & $2.6-2.8$ & $3.0-3.2$ \\
\hline $\begin{array}{l}\text { average pollen/ovule ratio in } \\
\text { thousands (range in parentheses, } n=2 \text { ) }\end{array}$ & $12(0)$ & $210(166-253)$ & $67(62-73)$ \\
\hline pollen grain, length (range in $\mu \mathrm{m}$ ) & $28-32$ & $27-31$ & $32-36$ \\
\hline pollen grain, exine sculpturing & perforate & perforate & foveolate \\
\hline $\begin{array}{l}\text { average diam. of perforations } \\
\text { of pollen grains }(\mu \mathrm{m}, n=5)\end{array}$ & 0.2 & 0.5 & 1.2 \\
\hline ovary, haircovering & glabrous & glabrous & hairy \\
\hline ovary, sclereids & absent & absent & present \\
\hline
\end{tabular}


shrubs. The terrain is characterized by poorly drained soils that are inundated in the rainy season. Lower lying terrains are permanently under water and dominated by Nypa fruticans Thunb. and Acrostichum aureum L.

Observations on Licuala distans were made at the Sri Phangnga National Park (SPNP) where this species is locally common. Licuala peltata var. sumawongii was observed in the Peninsular Botanical Garden in Khao Chong (PBG), Province of Trang, near the fringes of the surrounding hill Dipterocarp forest.

\section{Field observations}

Field observations were conducted in Oct-Nov 1992. A $10 \times 10 \mathrm{~m}$ plot was established at both the study sites for Licuala spinosa. All reproductive individuals found within these plots were marked ( $n=8$ at TKA; $n=9$ at KNC). Phenology and inflorescence development were studied on the individuals at KNC during the period 5-24 Oct. All inflorescences were labelled and growth rates of peduncle, rachis, first-order branches, and rachillae monitored. Numbers of flowers, buds per rachilla, number of rachillae per inflorescence, and number of inflorescences per palm were counted. Detailed studies of flowering biology and insect visitation were conducted at both study sites by continuous observation over a 24 hour period. Close-up photographs of flowers in different phases were taken (Fig. 3) and the adhesive capacity of the pollen grains tested by touching the anthers with a clean glass slide. The presence and relative quantity of nectar was determined and numbers and behaviour of visiting insects noted. In addition a representative sample of insect visitors were caught and preserved in alcohol for later identification and determination of pollen load. At TKA flowers in different developmental stages were collected and fixed in Navashin's solution for study of changes on the stigmatic surfaces. Insects were identified to family using Jensen (1987), Ross (1965) and Unwin (1981, 1984).

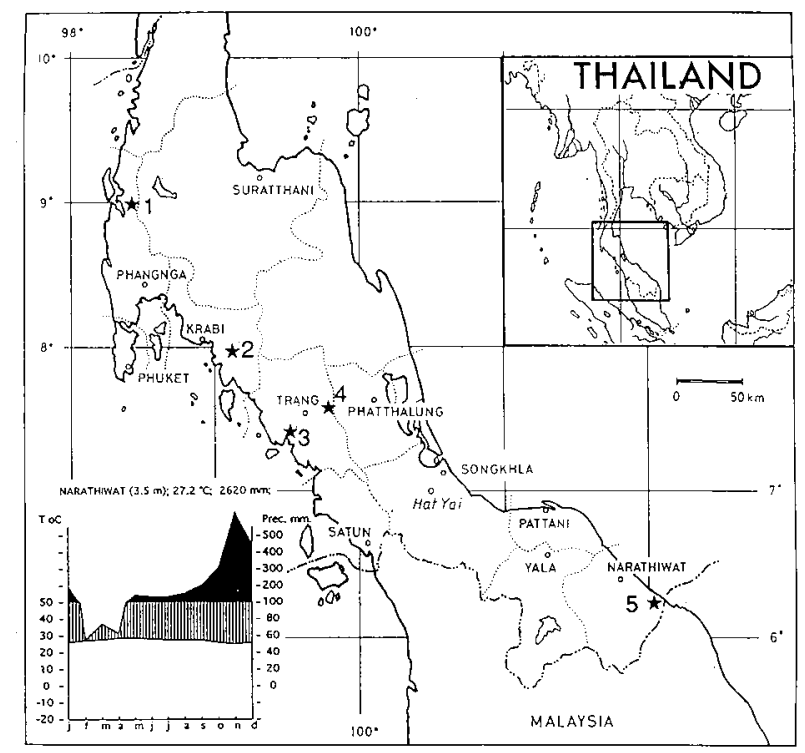

Fig. 2. Study sites in Peninsular Thailand. 1. Sri Phangnga National Park. 2, Khao Nor Chuchi Lowland Forest Project (KNC). 3, Thung Kai Arboretum (TKA). 4. Peninsular Botanical Garden in Khao Chong (PBG). 5, Narathiwat. 
Observations of inflorescence development, flowering biology and insect visitors of L. distans and L. peltata var. sumawongii were made over a few days in late October. For both species the number of flowers per rachilla and per inflorescence were determined and flowers sampled for later studies of morphology, anatomy and $\mathrm{P} / \mathrm{O}$ ratio. For L. distans a number of flowers in different phases were additionally collected and fixed in Navashin's solution for later study of flower development.

Voucher specimens of L. spinosa and L. distans from all study sites are deposited in AAU, BKF and $\mathrm{K}$.

\section{Laboratory analysis}

Flowers fixed in Navashin's solution were prepared for anatomical study by desilicification in hydrofluoric acid for 1 or 2 days. After this treatment, they were gradually dehydrated with ethanol and embedded in Technovit $7100^{\mathrm{TM}}$. Serial sections 7-8 microns thick were prepared on a Reichert ${ }^{\mathrm{TM}}$ rotary microtome. The sections were stained with toluidine-blue or ferric chloride for examination of tannin content and mounted in EuparalTM. For scanning electron microscopy (SEM) the dehydrated flowers were critical point dried using a BIO RAD CPD $750^{\mathrm{TM}}$, sputter coated with platinum, and examined with a Jeol JSM-840 ${ }^{\mathrm{TM}}$ scanning electron microscope. To estimate the pollen:ovule $(\mathrm{P} / \mathrm{O})$ ratio all pollen grains in one anther were extracted and counted. The estimates were based on anthers from at least two different
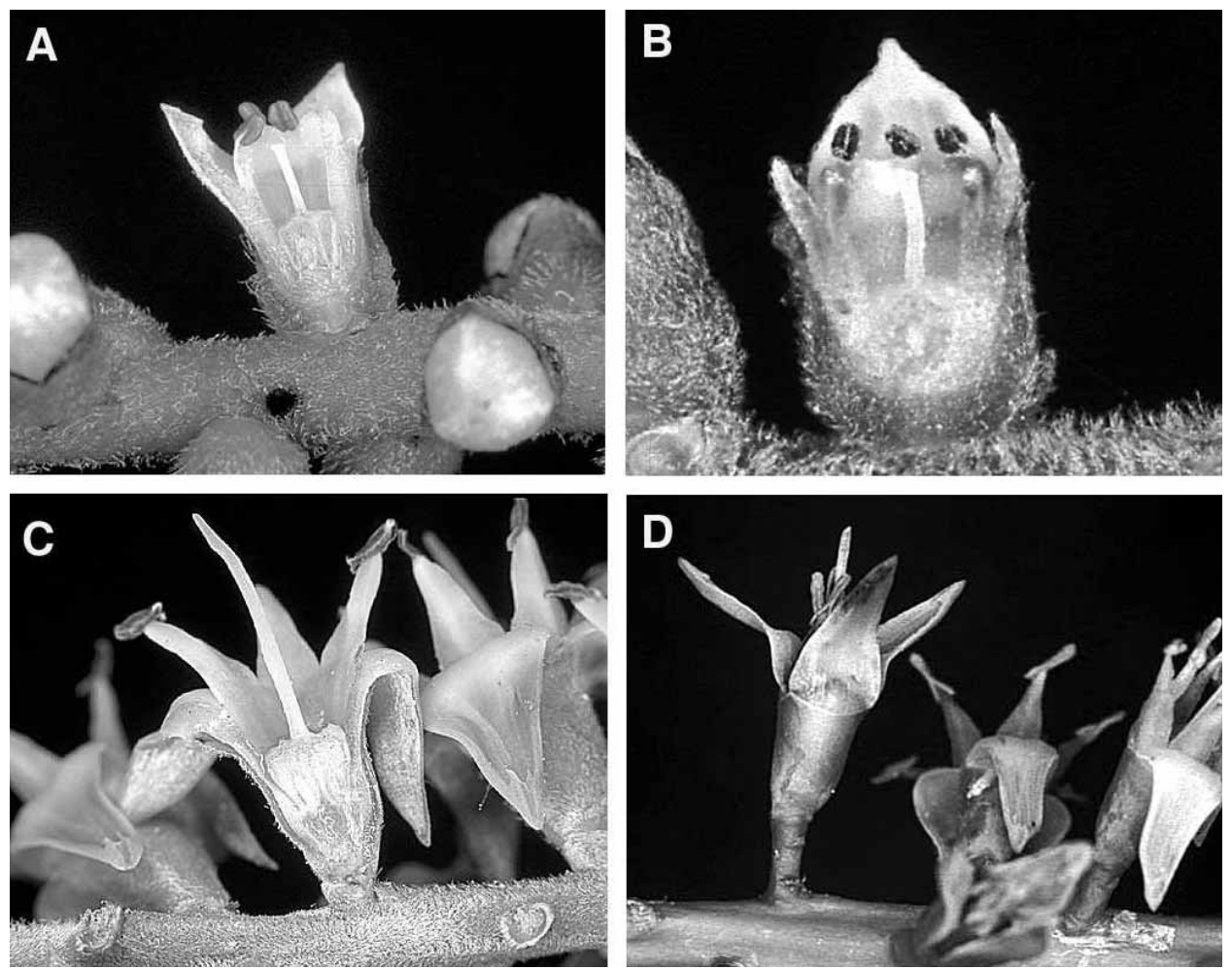

Fig. 3. Licuala flowers. a, L. spinosa. LS of flower in early male phase. $\mathbf{b}$, L. spinosa. LS of flower in receptive phase. c, L. peltata. LS of flower in late male phase. d, L. distans. 
individuals. Surface pollen load of insect visitors was determined by ethanol washing followed by centrifugation. The pellet was smeared on glass slides, embedded in glycerine, and the number of Licuala and foreign pollen, respectively, counted under a light microscope.

\section{Results}

\section{Phenology}

Flowering of the three Licuala species studied is synchronized with rainfall patterns. In Licuala spinosa flowering is apparently triggered by the onset of the rainy season. Licuala peltata flowered at the end of the rainy season, whereas L. distans flowered at the beginning of the dry season in 1994. It should be noted, however, that variation in phenological patterns occur within L. spinosa, probably as a facultative response to differing growth conditions. Thus in KNC, sun-exposed individuals flower once a year, whereas we did not observe an annual flowering cycle in shaded individuals growing nearby.

The first individuals of Licuala spinosa studied at KNC were in an advanced state of flowering on Oct 14. The last palm to flower had about $40 \%$ of its flowers in bud on Oct 25. On this basis, we estimate that flowering of the entire population lasted from mid September to mid November in 1992, peaking in October. Fruits of L. spinosa are normally mature in February. Prior to anthesis the rachillae elongated fast, while the length of the peduncle and rachis increased only negligibly. The rachillae on the proximal partial inflorescence grew faster than those of the distal partial inflorescence. After onset of anthesis, longitudinal expansion almost ceased.

Flowering in Licuala spinosa proceeded in an acropetal pattern. The first flowers to open were typically found on the distal rachillae of the proximal partial inflorescences. The proximal partial inflorescences still presented flowers when anthesis started in the distal partial inflorescence. The opening of the single to paired flowers is not synchronized. Two pulses of flowering usually occur on each rachilla, the first pulse being the most intensive. The number of flowers opening per day in one rachilla varied from 1-27 $(n=311)$. Detailed phenological observations were made on four inflorescences that began to flower immediately after we arrived on Oct 5 . The total number of flowers that open per day, per inflorescence, increases steadily to about 150-250 during the first 8-10 days of anthesis. Hereafter, the number begins to decline. Based on these observations we estimate that one inflorescence stays in anthesis for about 30 days.

Inflorescence development and flowering in L. distans and L. peltata followed a pattern different from that observed in L. spinosa. The proximal spicate rachilla branches flowered first. The overall sequence of flowering is thus acropetal. Flowering of the individual rachillae, however, was basipetal and of short duration. On the first day of flowering, only a few buds in the distal end of the rachilla opened (mean 5.20, range $1-7, n=5)$. The next three days about one-third of the remaining flowers opened each day (mean 30.75, range 25-40, $\mathrm{n}=4$ ) in the following way: on the second day of flowering all remaining buds in the distal third part of the rachilla opened; on day 3 the flowers in the central third of the rachilla opened; and on day 4, the flowers in the basal third part opened. 


\section{Flowering biology}

Flowers of all three species were protandrous (Fig. 3). In L. spinosa the buds opened in the morning of day 1 and in most cases dehiscence of the anthers started 2 hours hereafter (Fig. 4). Sometimes the anthers dehisced immediately after opening of the bud. Dehiscence occurred earlier and proceeded faster in flowers that were exposed to the sun. Flowers emitted a sweet, honey-like scent, and a small amount of nectar was observed around the ovaries of the flowers. The androecium started wilting early at night on day 1 . It gradually turned dark brown, as did the anthers and the petals.

In Licuala distans and L. peltata flowers were still open on day 3 and the stigmas were probably receptive. Abundant nectar production was observed both during staminate and pistillate phases ( $3 \mu \mathrm{l}$ was easily sucked up using a micropipette). The nectar had a sweet taste and a glucose test showed positive reaction. Anthesis was accompanied by a sweet, honey-like scent, resembling that observed in L. spinosa.

To estimate the duration of the receptive phase, flowers of Licuala spinosa were collected in different stages of development and fixed (Fig. 5). The starting point is the late bud, approximately one day before anthesis (phase 0 ). At this stage the stigma has three conspicuous lobes that are closely bunched together (Fig. 5a). Phase I corresponds to the newly opened flower at 07:20 with just a few dehisced anthers. At this stage the stigma lobes are straight. Only the papillae at the apex are exposed with few pollen grains adhering to them (Fig. 5b). Flowers in phase II were collected at 13:45 on day 1 of flowering. All the anthers had dehisced. The stigma lobes are slightly more reflexed and conspicuous. The papillae have enlarged, but few pollen grains adhere to the stigmatic surface (Fig. 5c). Phase IIIa corresponds to stages collected at 01:00 on day 2 of flowering. At this time, the staminal tube has turned light brown and a dense layer of newly germinating pollen covers the stigma (Fig. 5d). Adhesion of the pollen grains is probably facilitated by a combined effect of the glutinous stigmatic fluid and the enlarged papillae. The stigmas are thus receptive before the arrival of the first insect visitors to the flowers at dawn. Early germination of the pollen grains makes selfpollination a possibility, provided that the flowers are self-compatible. Later, in phase $I I I b \mathcal{E} c$, an enlargement of the papillae is visible (Figs 5e, 5f) and even more pollen grains adhere to the stigma. Phase IV stages were collected at 06:00 on day 2 of

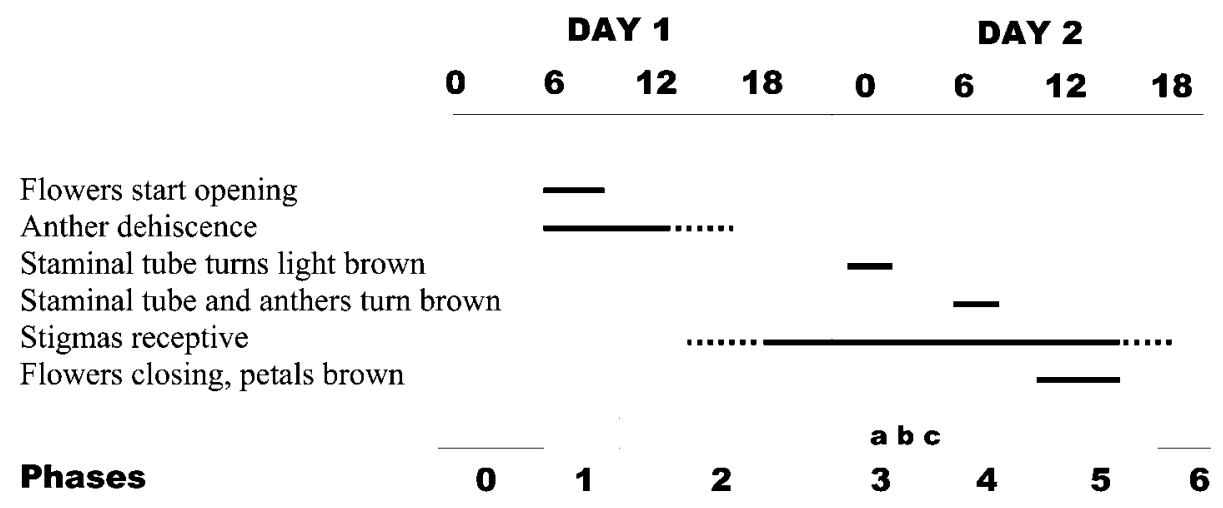

Fig. 4. Phenological events in Licuala spinosa. 

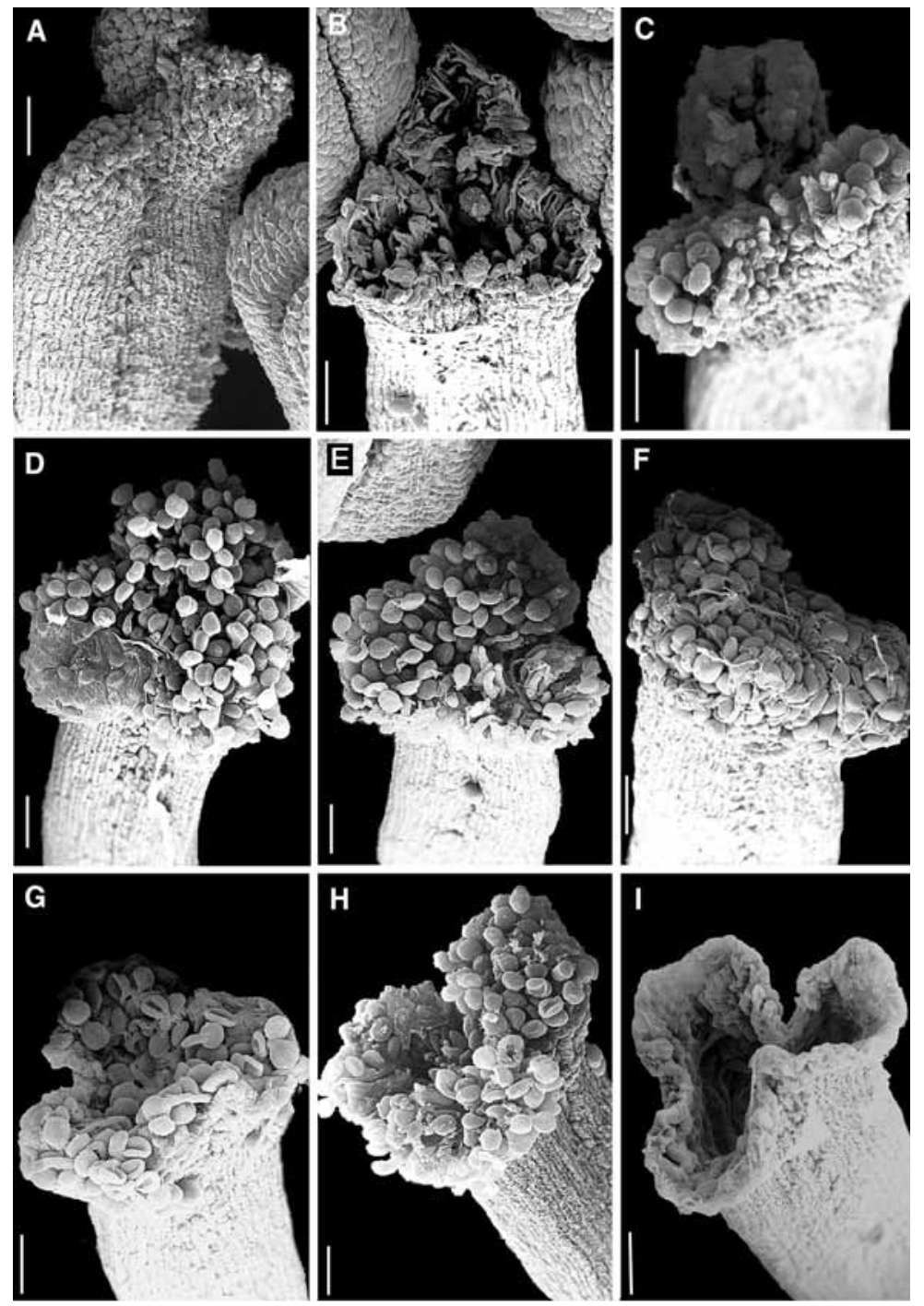

Fig. 5. Development of receptivity in Licuala spinosa. a, phase 0. Stigma in the late bud, approximately one day before anthesis. At this stage the stigma has three lobes that are closely bunched together. $\mathbf{b}$, phase I. Stigma in a newly opened flower at 7:20 am. The flower is in the ealy male phase with a few dehisced anthers. The stigmatic lobes are little reflexed with only a few pollen adhering to them. c, phase II. Stigma at 1:45 pm on day 1 of flowering. All the anthers have dehisced. The stigma is slightly reflexed and slightly three-lobed. Notice also the enlarged papillae in this stage. $\mathbf{d}$, phase IIIa. Beginning of female phase at 01:00 am on day 2 of flowering. The staminal tube has turned light brown. The stigma is covered with newly germinating pollen. The stigmatic lobes are clearly discernible and reflexed at this stage. Early receptivity and germination of the pollen makes self-pollination a possibility in this stage. e-f, phases IIIb $\mathcal{E} c$. The staminal tube and the stamens have turned brown and the papillae are further enlarged. g, phase IV. At 06:00 am on day 2 of flowering, a shallow depression appears on the stigma. The stigma is still covered with pollen and the lobes are further reflexed. The pollinating insects are reappearing at this stage. $\mathbf{h}$, phase $V$. The flower passes into this phase when the petals turn brown and close the flower by curving inward. i, phase VI. The flowers are closed, dark-brown and past the receptive phase. The papillae have desintegrated so that the opening of the stylar canal is visible. Scale bar $=50 \mu \mathrm{m}$ 
flowering. The staminal tube and the stamens are brown (Fig. 5g). The insects start reappearing at this stage. The pollen load on the stigma is heavy and the stigmatic lobes are further recurved. The flower passes into phase $V$ when the petals turn brown and close the flower by curving inward. At this time, a depression appears on the stigma (Fig. 5h). In a few cases reopening of the flowers took place on day 3 (phase $\mathrm{Va}$ ). No apparent changes were recorded in the stigma relative to the previous phase. Phase $V I$ corresponds to the closed and dark-brown flowers past the receptive phase (Fig. $5 \mathrm{i}$ ). The papillae have disintegrated so that the opening of the stylar canal is visible.

Changes in the stigma during the different phases of flowering were also studied in Licuala distans, but in less detail. In this species the receptive surfaces are lining the inside of the tubular stylar canal. At staminate anthesis on day 1, the rim surrounding the opening of the stylar canal is curved inwards. Few pollen grains were observed on the reduced stigmatic surface at this point (Fig. 6a). During the receptive phase on day 2, only a slight reflexion of the stigmatic margins occurs (Fig. 6b). On day 3, a shallow depression on the stigmatic surface is seen (Fig. 6c). The stigma of L. peltata is morphologically very similar to that of $L$. distans and probably passes through the same stages. The stigmatic surfaces of both species are less reflexed than those of L. spinosa and have fewer adhering pollen grains.

\section{Insect visitors}

Licuala spinosa. A range of insects belonging to eight different orders visited the flowers (Table 2). The first insects arrived at the flowers just after sunrise around 06:00 and insect activity continued until sunset, apparently peaking somewhere between 10:00 to 11:00 with a maximum of 20 visits per hour. During the night there was almost no activity and only one moth and one Thysanoptera were observed. Apart from insects, Orange-Bellied Flowerpeckers (Dicaeum trigonostigma) and a few spiders were also observed among the visitors, probably preying on the insects. Representatives of Anisoptera and Zygoptera apparently used the inflorescence as a resting place and were not observed to be in contact with the inner parts of the flowers. Cicadoidea, Formicidae, Lepidoptera and Thysanoptera were also recorded but their presence was erratic. Potentially important pollinators should consequently be looked for among insects of the orders Coleoptera, Diptera and Hymenoptera.
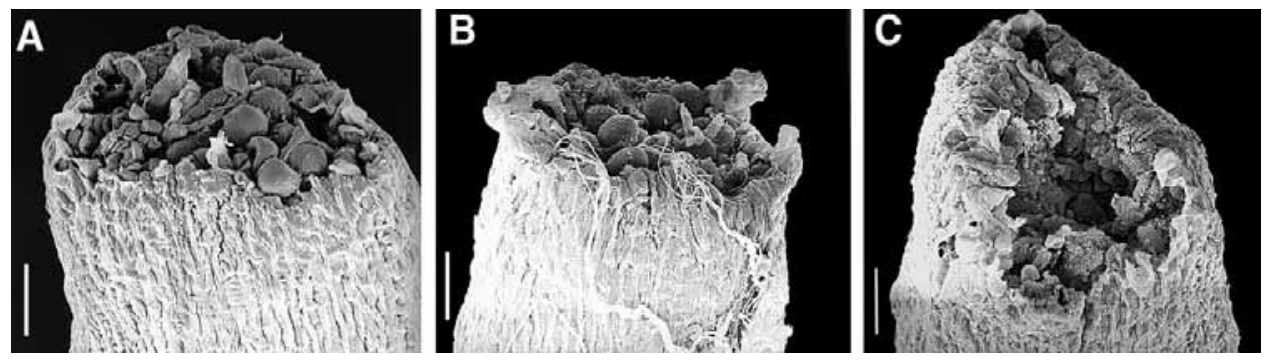

Fig. 6. Development of receptivity in Licuala distans. a, At male phase on day 1, the rim surrounding the opening of the stylar canal is curved inwards. Few pollen grains were observed on the reduced stigmatic surface in this stage. $\mathbf{b}$, During the female phase on day 2 , the stigmatic margins are only sligthly recurved. c, On day 3 , a shallow depression on the stigmatic surface is seen. Scale bar $=50 \mu \mathrm{m}$. 
Some differences in insect visitor activity were noted between the two sites where L. spinosa was studied. In KNC a larger number of insect species was observed whereas a higher number of individuals were present in TKA.

Surface pollen loads of insect visitors (Table 3) varied from 0-785 pollen of Licuala spinosa per individual. The highest values were recorded for halictid bees and some species of the Calliphoridae. However, Halictid bees were only observed in flowers in the staminate phase. Calliphorid and also Tachinid flies were both observed with their proboscises inserted deep into the flowers throughout all phases, presumably engaged in extracting nectar.

Licuala distans. At 09:40 there was activity of bees around the inflorescence. The bees were mostly stingless Trigona spp. but also a few Apis were observed. No flies were seen in the flowers. The stingless bees arrived continuously until 11:20 when observations stopped and visited flowers both in the staminate and the pistillate phases. Examination of the surface pollen loads of the visiting Trigona-bees showed that these had relatively high loads (Table 3).

Table 2. Visiting insects to the inflorescences of Licuala spinosa

\begin{tabular}{|c|c|c|c|}
\hline \multirow[t]{2}{*}{ Order } & \multirow[t]{2}{*}{ Family } & \multicolumn{2}{|c|}{ Number of individuals of visting insects } \\
\hline & & Khao Nor Chuchi & $\begin{array}{l}\text { Thung Kai } \\
\text { Arboretum }\end{array}$ \\
\hline Anisoptera & & 1 & \\
\hline Coleoptera & Cerambycidae & 3 & \\
\hline \multirow[t]{7}{*}{ Diptera } & Calliphoridae & 14 & 33 \\
\hline & fam. unknown 1 & 1 & \\
\hline & fam. unknown 2 & & 42 \\
\hline & fam. unknown spp. & 6 & 19 \\
\hline & Empididae & 2 & \\
\hline & Platystomatidae & & 1 \\
\hline & Tachinidae & 8 & 11 \\
\hline \multirow[t]{2}{*}{ Hemiptera } & Cicadidae & 4 & \\
\hline & Membracidae & 1 & \\
\hline \multirow[t]{3}{*}{ Hymenoptera } & Eumenidae & 9 & 16 \\
\hline & Formicidae & 2 & \\
\hline & Halictidae & 6 & 20 \\
\hline Lepidoptera & & 4 & 18 \\
\hline Thysanoptera & & 2 & 1 \\
\hline Zygoptera & & 5 & \\
\hline
\end{tabular}


Table 3. Average pollen loads for visiting insects (insects that do not not carry pollen grains of the species of Licuala visited have been excluded)

\begin{tabular}{|c|c|c|c|c|c|}
\hline \multirow[t]{4}{*}{ Order } & \multirow[t]{4}{*}{ Family } & \multicolumn{4}{|c|}{ Average pollen load per visitor } \\
\hline & & \multirow{2}{*}{\multicolumn{2}{|c|}{$\begin{array}{l}\text { Licuala spinosa } \\
\text { Khao Nor Chuchi }\end{array}$}} & \multirow{2}{*}{\multicolumn{2}{|c|}{$\begin{array}{l}\text { Licuala spinosa } \\
\text { Thung Kai } \\
\text { Arboretum }\end{array}$}} \\
\hline & & & & & \\
\hline & & own & alien & own & alien \\
\hline Araneae & & 3 & 7 & 0 & 2 \\
\hline \multirow[t]{3}{*}{ Coleoptera } & Cerambycidae sp. 1 & 105 & 9 & & \\
\hline & Cerambycidae sp. 2 & 5 & 21 & & \\
\hline & Cerambycidae sp. 3 & 7 & 12 & & \\
\hline \multirow[t]{10}{*}{ Diptera } & Calliphoridae sp. 1 & 0 & 6 & & \\
\hline & Calliphoridae sp. 2 & 483 & 53 & & \\
\hline & Calliphoridae sp. 3 & & & 42 & 7 \\
\hline & Calliphoridae sp. 4 & & & 65 & 5 \\
\hline & Empipidae & 6 & 24 & & \\
\hline & Platystomatidae & & & 6 & 71 \\
\hline & Tachinidae & 123 & 41 & & \\
\hline & fam. unknown sp. 1 & & & 10 & 17 \\
\hline & fam. unknown sp. 2 & & & 1 & 7 \\
\hline & fam. Unknown sp. 3 & 20 & 21 & & \\
\hline Hemiptera & Membracidae & 8 & 7 & & \\
\hline \multirow[t]{6}{*}{ Hymenoptera } & Eumenidae sp. 1 & 86 & 57 & & \\
\hline & Halictidae sp. 1 & 4 & 20 & & \\
\hline & Halictidae sp. 2 & 785 & 776 & & \\
\hline & Halictidae sp. 3 & 269 & 2 & & \\
\hline & & \multicolumn{2}{|c|}{$\begin{array}{l}\text { Licuala peltata } \\
\text { cultivated }\end{array}$} & \multicolumn{2}{|c|}{$\begin{array}{l}\text { Licuala distans } \\
\text { Sri Phangnga }\end{array}$} \\
\hline & & own & alien & own & alien \\
\hline Hemiptera & Meridae & & & 0 & 0 \\
\hline \multirow[t]{8}{*}{ Hymenoptera } & Apidae, Trigona sp. 1 & & & 111 & 1 \\
\hline & Apidae, Trigona sp. 2 & & & 283 & 1 \\
\hline & Apidae, Trigona sp. 3 & & & 167 & 7 \\
\hline & Apidae, Trigona sp. 4 & & & 641 & 210 \\
\hline & Apidae, Trigona sp. 5 & & & 1547 & 22 \\
\hline & Apidae, Trigona sp. 6 & 1584 & 19 & & \\
\hline & Apidae, Trigona sp. 7 & 2106 & 36 & & \\
\hline & Eumenidae sp. 2 & 29 & 107 & & \\
\hline
\end{tabular}


Licuala peltata. Only a few insects were observed near flowering individuals of L. peltata var. sumawongii cultivated in the palm field of the Peninsular Botanical Garden in Khao Chong (observations made from 08:00 to 11:30). A few honey bees (Apis) were seen collecting pollen from flowers in the staminate phase (3 observations). A large wasp belonging to the Eumenidae was seen moving around in the flowers of the palm (4 observations). The Trigona-bees were the most frequent visitors in flowers both during staminate and pistillate phases and had the highest pollen load (Table 3).

\section{Test for selfing in Licuala spinosa}

Rachillae bagged with nets impenetrable to insects (6 rachillae with a total of 187 flowers) showed a fruiting success of $3.4 \%$, comparable with that of unbagged inflorescences from adjacent palms growing in shady conditions (5.5\%; 2 rachillae with a total of 145 flowers). Licuala spinosa is thus potentially self-compatible.

\section{Pollen/Ovule ratio}

The variation of $\mathrm{P} / \mathrm{O}$ ratios within palms often reflects pollination mode since pollen is offered as a reward particularly in the case of bee pollination. The following ratios were recorded for the species studied: Licuala distans 210 (range 166-253, n=2); L. peltata 67 (range $62-73, \mathrm{n}=2$ ) and L. spinosa 12 (no variation, $\mathrm{n}=2$ ). In L. peltata, many undeveloped pollen grains were observed. These were not included in the calculation.

\section{Floral anatomy}

Sections of the flowers of all three species of Licuala (Fig. 7) revealed the presence of idioblasts containing bundles of needle-shaped calcium oxalate crystals (raphides), which probably serve to protect the flowers from herbivory during their prolonged phase of anthesis. Raphides were found mostly in the staminal tube, but they also occur in the ovary and the fleshy part of the sepals. All three species had tannins evenly distributed throughout the floral parts and the calyx was heavily sclerified. Numerous sclereids were found in the petals of L. distans and in the ovary of L. peltata.

Cross-sections of the flowers revealed the presence of two types of nectaries. In some species the nectar flow is raised by undulation and convolution of the septal nectaries. This labyrinthine kind of nectary (Schmid 1983) is found in L. distans and L. peltata (Figs. 7a \& c). In L. spinosa nectar secretion only occurs in the cavities created by the adjoining septal radii of the ovary (simple type). The nectar is discharged at the base of the ovary. The outline in transverse section is like a circle with three T-formed appendices (Figs. $7 \mathrm{~b} \& \mathrm{~d}$ ).

\section{Discussion}

The study of pollination modes within the subgenera Licuala and Libericula respectively has revealed fundamental differences.

Licuala spinosa, the only representative from subgenus Licuala included in this study, is characterised by having ramified partial inflorescences, small and inconspicuous flowers and an erratic flowering sequence. The entire inflorescence constitutes a functional unit that flowers for approximately one month. Limited amounts of nectar are discharged from secretory epithelial cells that are located at the bottom of the septal slits. The flowers are well protected during the long exposure in bud by 
structural and chemical defences such as sclerified tissues and tannin. The narrow opening of the staminal tube assures that only small insects get access to the nectar. Interestingly the staminal tube has a higher concentration of raphide containing idioblasts than the two other species in this study.
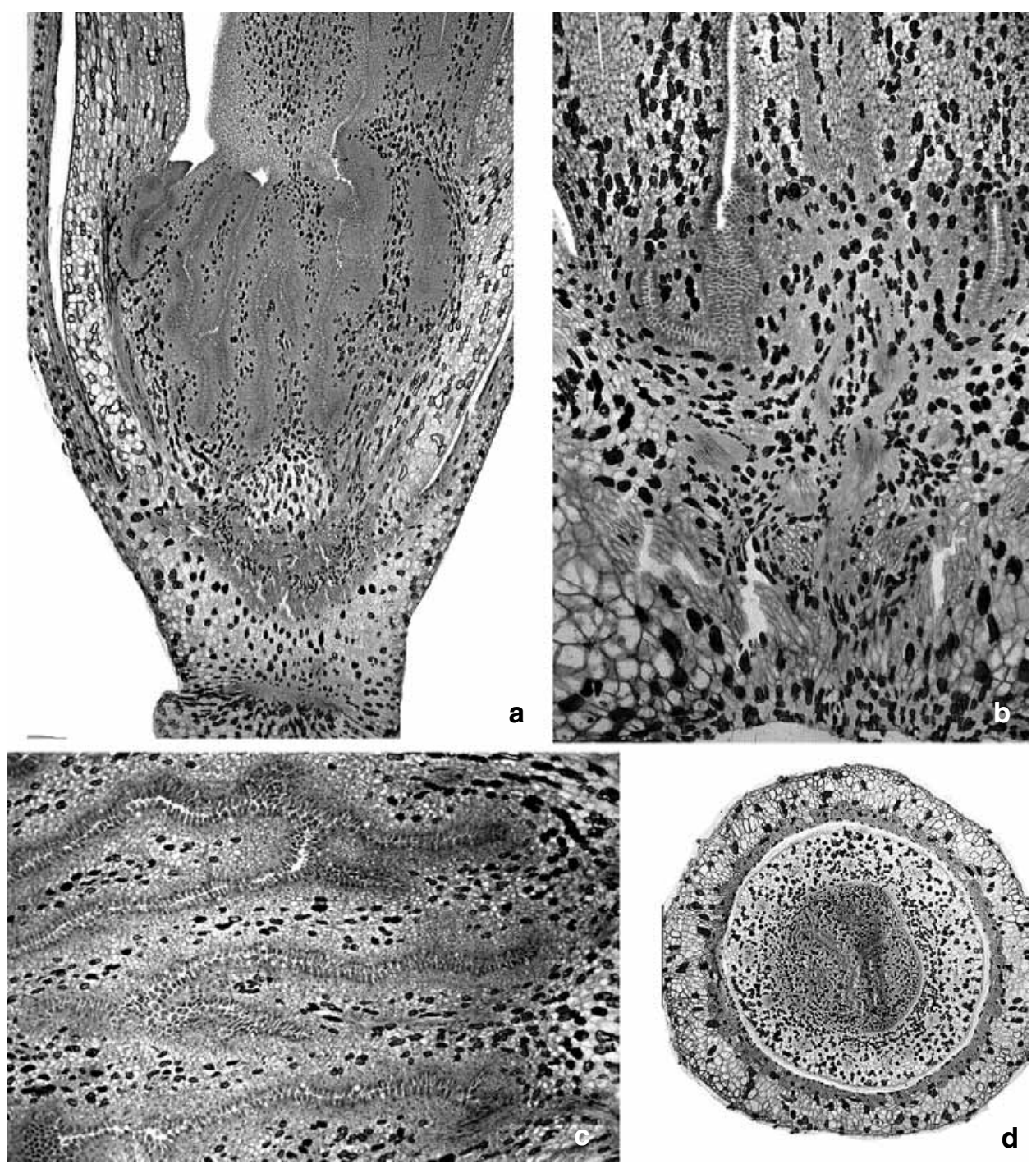

Fig. 7. Anatomical preparations of L. spinosa and L. distans. a, L. distans. LS of basal part of flower. Notice the densely staining labyrinthine nectaries below the gynoecium and the dark coloured tannin-containing cells scattered throughout. b, L. spinosa. LS of flower. Notice the densely staining nectaries in the bottom of the septal slits and the dark coloured tannin-containing cells scattered throughout. c, L. distans. Detail of LS of labyrinthine nectaries. d, L. spinosa. CS of the flower. The nectaries line the bottom of the septal slits. Notice their T-shape towards the periphery of the gynoecium. 
Brown (1982) observed that sub-canopy trees of Sabal palmetto Lodd. ex Schult. f. flowered later compared to trees exposed to sunlight. In many fly-pollinated species there has been reported a lack of seasonality in the flowering of several species (Kwan 1959, Skov \& Balslev 1989, Borchsenius 1993, Schmid 1970). This is probably an effect of the stable microclimatic conditions that prevail throughout the year in the understorey of mature phase forest patches where these species typically occur. In KNC we observed sun-exposed individuals of $L$. spinosa that flowered in annual cycles. Flowering is apparently triggered by the first rains of the rainy season. Individuals of the same species occurring in the forest nearby produced inflorescences throughout the year. Observations throughout Thailand have shown that Licuala spinosa is a versatile species that thrives well under both light open and forest conditions, as long as there is a constant water supply. Other species of Licuala probably have a more uniform phenology and require shaded and undisturbed conditions.

The study of populations of L. spinosa in two contrasting habitats revealed variation in the populations of visiting insects. In both the light-open Parklands at TKA and in the forest understorey at KNC flies and eumenid and halictid bees were numerous. We ascribe the bees a minor role in transferring pollen grains since they were only observed in flowers in the male phase. In the forest situation the diversity of visitors was greater but the total number of visits smaller. The pollination success was limited corresponding to that of inflorescences bagged for selfing. The detailed study of receptivity further shows that self-pollination is possible during an overlap between the male and female phases before the insects reappear at sunset (phase III). The stamens and the stigma are situated closely to each other in the flower (Figs $3 a$ \& b). The pollen loads carried by the visiting insects further indicate the dominating role of especially calliphorid and tachinid flies in transferring pollen grains in this species. The low $\mathrm{P} / \mathrm{O}$ ratio combined with the low amount of nectar confirms that the award offered to visiting bees is limited.

In L. peltata, the partial inflorescences are spicate and function as distinct units. The flowers are large and conspicuous. The filaments are fused basally only and form a wide cup-like structure. Opening of the flowers is under strict control and proceeds as a basipetal pulse that last 4-5 days. Licuala distans is similar to L. peltata in most of the above-mentioned aspects. The flowering is, however, more intensive in this species due to more inflorescences at anthesis at the same time and branching of the partial inflorescences. A high concentration of sclerified tissue is found in the petals of L. distans and in the ovary of L. peltata. The staminal tube of L. peltata is characterized by an almost lack of raphide containing idioblasts. Based on morphological and anatomical features, it is tempting to conclude that specialisation of pollination has proceeded further in L. peltata. This assumption is, however, contradicted by the fact that the $\mathrm{P} / \mathrm{O}$ ratio is higher in L. distans. Compared with L. spinosa self-pollination is less likely in subgenus Libericula since the stigmas are well separated from the anthers in the flower (Figs $3 \mathrm{c} \& \mathrm{~d}$ ). The inward curved rim that surrounds the opening of the stylar canal at anthesis furthermore restricts the receptive surfaces of the stigma.

The labyrinthine nectaries are situated below the gynoecium in both $L$. distans and L. peltata. Copious amounts of nectar are produced thanks to undulations and convolutions of the nectariferous tissues. This makes the flowers attractive to insects with high energy requirements such as bees. Additional ontogenetic studies by Barfod and Stauffer (in progr.) will hopefully throw more light on the origin of this specialized type of nectary. Interestingly, a member of subgenus Licuala, L. merguensis Becc. (syn. Licuala hirta Hodel), has been observed to have a labyrinthine type of nectary (Barfod \& Saw 2002). This species is characterized by having yellow flowers, a colour that is often found in bee-pollinated palm species. 
The mutualistic interaction between pollinating insects and flowers is mediated by the scent and colour of the flower and the nutritional value of nectar and pollen grain (Harborne 1988). Pollination by flies or myophily has been reported in a wide range of palms such as Aiphanes eggersii Burret (Borchsenius 1993), Geonoma irena F Borchsenius and G. cuneata H. Wendl. ex Spruce (Borchsenius 1997). Flies do not nurse their brood and only need food for their own consumption, usually in the form of energy-rich nectar. Representatives of the families Calliphoridae, Syphidae (hover flies) and Drosophilidae (fruit flies) have often been reported as visiting palms. Although hover flies and fruit flies are often listed among the visitors to palm inflorescences they rarely have a major role in transferring pollen. In Licuala spinosa the evidence strongly suggests that Calliphorid flies probing for nectar are the major contributors to pollination. Promiscuity is probably widespread as evidenced by the little overlap between pollinators at the two study sites. Myophily is particularly widespread in understorey palms. Flies are not busy food collectors and are inefficient pollinators compared to insects that nurse their brood. Myophily is considered the least specialized type in the family (Howard et al. 2001).

Pollination by bees or melittophily is a widespread phenomenon in the tropics. Especially Trigona bees (stingless bees or sweat bees) are well known as visitors to palms (Bullock 1981, Bøgh 1996). However, they often act as pollen thieves (Búrquez et al. 1987) or can be ruled out as pollinators because they only visit male flowers (Essig 1971, Beach 1984, Barfod 1991, Kiew \& Muid 1989). The bees are attracted by a combination of pollen that is used for nursing the brood and sugar-rich nectar to satisfy a high energy demand. Usually the specificity of the interaction between bees and palms is low. The palm thus shares pollinators with a wide range of other plant species. In two species of subgenus Libericula studied, there was no overlap in the visiting species of Trigona. The stingless bees both collected pollen from the relatively large anthers and probed for nectar. The hoarding instinct of higher, social hymenoptera makes them more effective than flies as pollinators. Bees are typically attracted to brightly coloured zygomorphic flowers with mild scent. In palms they are typically found in species that allow for extensive foraging due to bunched flowers and large anthers that are easy to handle. Both Licuala distans and L. peltata match the behavior of Trigona bees well in their adaptations to pollination.

\section{Acknowledgments}

The authors wish to give a special thanks to director Dr Chawalit Niyomdham and forester Wiwat Ueachirakan from the Forest Herbarium, Royal Forest Department, Bangkok for logistic help and friendship. The fieldwork in Thailand was financed by a grant from SNF (11-0700-1 PD/jl). We also wish to thank 'Ingeniør Svend G. Fiedler og hustrus legat' for financial support to Tage Burholt. Special thanks is due to laboratory technician Anni Sloth for assistance in the laboratory. We are grateful for the joyful companionship of illustrator Kirsten Tind and Anders Bøgh during the fieldwork. We are grateful to Jens Mogens Olesen who provided many useful comments to an early draft of the article.

\section{References}

Ambwani, K. \& Kumar, M. (1993) Pollen morphology of the coryphoid genus Licuala (Palmae). Grana 32: 164-168.

Anderson, A.B., Overall, W.L., \& Henderson, A. (1988) Pollination ecology of a forest-dominant palm (Orbignya phalerata Mart.) in northern Brazil. Biotropica 20: 192-205. 
Anstett, M.C. (1999) An experimental study of the interaction between the dwarf palm (Chamaerops humilis) and its floral visitor Derelomus chamaeropsis throughout the life cycle of the weevil. Acta Oecologica 20: 551-558.

Barfod, A.S. (1991) A monographic study of the subfamily Phytelephantoideae (Arecaceae). Opera Bot. 105: 1-72.

Barfod, A.S. \& Saw, L.G. (2002) The genus Licuala (Arecaceae, Coryphoideae) in Thailand. Kew Bulletin 57: 1-26.

Bawa, K.S. (1979) Breeding systems of trees in a tropical wet forest. New Zealand J. Bot. 17: 521-524.

Beach, J.H. (1984) Reproductive biology of the peach or "pejibayé" palm (Bactris gasipaes) and a wild congener (B. porschiana) in the Atlantic lowlands of Costa Rica. Principes 28: 107-119.

Bernal, R. \& Ervik, F. (1996) Floral biology and pollination of the dioecious palm Phytelephas seemannii in Colombia: an adaptation to staphylinid beetles. Biotropica 28: 682-692.

Bøgh, A. (1996) The reproductive phenology and pollination biology of four Calamus (Arecaceae) species in Thailand. Principes 40: 5-15.

Borchsenius, F. (1993) Flowering biology and insect visitation of three Ecuadorean Aiphanes species. Principes 37: 139-150.

Borchsenius, F. (1997) Flowering biology of Geonoma irena and G. cuneata var. sodiroi (Arecaceae). Pl. Syst. Evol. 208: 187-196.

Brown, K.E. (1982) Observations on the natural history of the Cabbage Palm, Sabal palmetto. Principes 26: 44-48.

Bullock, S.H. (1981) Notes on the phenology of inflorescences and pollination of some rain forest palms in Costa Rica. Principes 25: 101-105.

Búrquez, A., Sarukhán, J.K. \& Pedroza, A.L. (1987) Floral biology of a primary rain forest palm, Astrocaryum mexicanum Liebm. J. Linn. Soc. Bot. 94: 407-419.

Ervik, F. (1993) Notes on the phenology and pollination of the dioecious palms Mauritia flexuosa (Calamoideae) and Aphandra natalia (Phytelephantoideae) in Ecuador. Pp. 7-12, in Bartholdt et al. (eds), Animal-plant Interactions in Tropical Environments (Zoologisches Forschungsinstitut und Museum Alexander König: Bonn).

Ervik, F. \& Feil, J.P. (1997) Reproductive biology of the monoecious understorey palm Prestoea schultzeana in Amazonian Ecuador. Biotropica 29: 309-317.

Essig, F.B. (1971) Observations on pollination in Bactris. Principes 15: 20-24.

Ferguson, I.K. (1987) Observations on the variation in pollen morphology of Palmae and its significance. Can. J. Bot. 64: 3079-3090.

Ferguson, I.K. \& Harley, M.M. (1993) The significance of new and recent work on pollen morphology in the Palmae. Kew Bull. 48: 205-243.

Furtado, C.X. (1940) Palmae Malesicae. VIII. - The genus Licuala in the Malay Peninsula. The Gardens Bull. Straits Settlements 11(2): 31-73.

Harbourne, H.B. (1988) Introduction to ecological biochemistry. (Academic Press: London).

Henderson, A. (1986) A review of pollination studies in the Palmae. Bot. Rev. 52: 221-259.

Herrera, J. (1989) On the reproductive biology of the dwarf palm, Chaemerops humilis in Southern Spain. Principes 33: 27-32.

Howard, F.W., Moore, D, Giblin-Davis, R. M. and Abad, R. G. (2001) Insects on Palms. (CABI publishing: Wallinford).

Jensen, P.B. (1987) Nøgle til Hymenoptera. (Zoologisk Laboratorium: Aarhus Universitet).

Kiew, R. \& Muid, M. (1989) Bees and palms in Peninsular Malaysia. Principes 33: 74-77.

Knuth, P. (1904) Handbuch der Blütenbiologie. Bd. III (ed. E. Loew). (Wilhelm Engelmann: Leipzig).

Küchmeister, H., Gottsberger, G \& Silberbauer-Gottsberger, I. (1997). Pollination of Orbignya spectabilis, a "monocious" Amazonian palm. Pp. 67-76 in Bartholdt et al. (eds), Animal-plant interactions in Tropical Environments. (Zoologisches Forschungsinstitut und Museum Alexander König: Bonn).

Kwan, W.Y. (1959) Autecology of the Bertram Palm, Eugeissona triste Griff. Malayan Forester 22: 303-313.

Lepesme, P. (1947) Les Insectes des Palmiers. (Paul Lechevalier: Paris).

Listabarth, C. (1992) Insect induced wind pollination of the palm Chamaedorea pinnatifrons and pollination in the related Wendlandiella sp. Biodiversity and Conservation 1: 39-50.

Listabarth, C. (1996) Pollination of Bactris by Phyllotrox and Epurea. Implications of the palmbreeding beetles on pollination at the community level. Biotropica 28. 69-81.

Olesen, J.M. \& Balslev, H. (1990) Flower biology and pollinators of the Amazonian monoecious palm, Geonoma macrostachys: A case of Bakerian mimicry. Principes 34: 181-190. 
Ross, H.H. (1965) A Textbook of Entomology. (Toppan Company, Ltd.: Tokyo).

Saw, L.G. (1997) A revision of Licuala (Palmae) in the Malay Peninsula. Sandakania 10: 1-95

Scariot, A.O., Lieras, E. \& Hay, J. D. (1991) Reproductive biology of the palm Acrocomia aculata in central Brazil. Biotropica 23: 12-22.

Schmid, R. (1970) Notes on the reproductive biology of Asterogyne martiana (Palmae). I. Inflorescence and floral morphology; phenology. Principes 14: 3-9.

Schmid, R. (1983) Septal nectaries of Asterogyne martiana and other Palmae. Principes 27: 168-174.

Skov, F. \& Balslev, H. (1989) A Revision of Hyospathe (Arecaceae). Nord. J. Bot. 9: 189-202.

Uhl, N.W. (1969) Anatomy and ontogeny of the cincinni and flowers in Nannorrhops ritchiana (Palmae). J. Arnold Arbor. 50: 411-431.

Uhl, N.W. \& Dransfield, J. (1987) Genera Palmarum. (Allen Press: Lawrence, Kansas).

Unwin, D.M. (1981) A key to the families of British Diptera. Field Studies 5: 513-553.

Unwin, D.M. (1984) A key to the families of British Coleoptera. Field Studies 6: 149-197.

Zona, S. (1987). Phenology and pollination biology of Sabal etonia (Palmae) in southeastern Florida. Principes 31: 177-182. 
